\title{
A Scotch Violinist
}

Author(s): T. S.

Source: The Musical Times and Singing Class Circular, Vol. 39, No. 665 (Jul. 1, 1898), p. 485

Published by: Musical Times Publications Ltd.

Stable URL: http://www.jstor.org/stable/3366802

Accessed: 12-05-2016 06:14 UTC

Your use of the JSTOR archive indicates your acceptance of the Terms \& Conditions of Use, available at

http://about.jstor.org/terms

JSTOR is a not-for-profit service that helps scholars, researchers, and students discover, use, and build upon a wide range of content in a trusted

digital archive. We use information technology and tools to increase productivity and facilitate new forms of scholarship. For more information about JSTOR, please contact support@jstor.org.

Musical Times Publications Ltd. is collaborating with JSTOR to digitize, preserve and extend access to The Musical Times and Singing Class Circular 
shortly take up his new duties as conductor of the Munich Opera. - Dr. Eduard Lassen, the well-known composer and Court Capellmeister here has completed the score of a ballet entitled "Diana," the scenarium of which had been sketched out by the poet Heine, as a sequel to his "Göttin im Exil," for the Italian Opera, London, during Lumley's management, but which has never been made use of. The new work is to be brought out at the Munich Opera.

Wiesbaden.-Miss Mary Howe, the excellent American soprano, who recently appeared here in favourite parts with great success, has been definitely engaged at the Royal Opera for the next two years.

\section{OBITUARY.}

We regret to record the death of Richard LATTER, a well-known teacher of singing, which took place at Westbourne Lodge, Goldhawk Road, on the 2nd ult. Mr. Latter, who was born at Bromley, Kent, on July 22, I823, received his musical education at the Royal Academy of Music, of which Institution he was made an Associate in $1849 . \quad \mathrm{He}$ made his début in opera at the Princess's Theatre as Malatesta in "Don Pasquale," and also played in Birmingham, Manchester, and elsewhere up to $185 \mathrm{I}$. He then settled in Aberdeen and became conductor of the Aberdeen Choral Union. In this capacity he introduced many leading artists of the day to the granite city, including Grisi, Mario, Sims Reeves, and Santley. He was a captain in the Ist Aberdeenshire Volunteers. Leaving Aberdeen in 1871 , Mr. Latter came to London. He was appointed one of the professors at the opening of the Guildhall School of Music, where, up to the time of his death, he was a universal favourite. $\mathrm{He}$ also taught at the Royal Academy of Music and the Royal College of Music. The remains of Mr. Latter, who was a Freemason, were laid to rest in Kensal Green Cemetery.

The death is announced, on May 26, at Dresden, of EUgen KRANTz, the able director of the Royal Conservatorium in that capital, at the age of fifty-three. Born at Dresden in 1844 , he studied under Döring and Rietz, occupied the post of conductor of the chorus at the Royal Opera for some years as well as of the LehrerGesangverein, and after holding a professorship at the Conservatorium for a considerable time, became its director in $x 890$. In this latter position Krantz developed rare administrative qualities, combined with indefatigable zeal and much tact, by virtue of which he greatly raised the status of the Institution.

Edouard Joseph Mangeot, the well-known French musical journalist and mechanical inventor, died in Paris on May $3 \mathrm{I}$, aged sixty-four. A native of Nantes, he gained his practical experience at the pianoforte factory conducted in that town by his father, of which, on the latter's death, he became the chief. He was the inventor of the pianoforte with the double keyboard (à double clavier renversé), which caused such a sensation during the Paris Exhibition of 1878 , and which was introduced soon after to London audiences by its exponent par excellence, the Chevalier de Kontski. In 1889 M. Mangeot founded the journal Le Monde Musicale, of which he was the editor, and which occupies a highly honourable position in contemporary French musical journalism.

Professor Ferdinand Gleich, the doyen of Dresden musicians and musical authors, died at Langebrück, near the Saxon capital, on May 22, at the age of eighty-eight. He was a pupil of the Leipzig Conservatorium and was for a number of years associated with the management of the German Theatre in Prague. As musical critic of the Dresdener Anzeiger during a long period, his writings were much read, and his volumes, entitled "Die Hauptformen in der Musik" and "Handbuch der modernen Instrumentirung," are valuable contributions to theoretical musical literature.

On the gth ult., at 8 , Spenser Road, Herne Hill, FREDERICK LUCAS, late of Great Marlborough Street, died in his seventy-eighth year. Mr. Lucas was an accountant, who for many years chiefly practised amongst and for music firms, and was for many years one of the auditors of the Choir Benevolent Fund.

\section{CORRESPONDENCE.}

\section{A SCOTCH VIOLINIST.}

TO THE EDITOR OF "THE MUSICAL TIMES."

SIR,-With your permission I should like to correct a mistake in your biographical notice of Sir A. C. Mackenzie where it is stated that his father was the first Edinburgh musician that finished his education on the Continent.

Alexander Murray was a well-known violinist in Edinburgh and Scotland in the twenties and thirties. He was born at the commencement of the century, and finished his education on the Continent under Spohr, Baillot of Paris, and Mayseder of Vienna. He was well known here, having been soloist at several concerts (in the thirties) of the Belfast Anacreontic Society, and also at the opening concert in the Society's new Music Hall, in March, 1840. Good terms having been offered him by the Society as leader, he remained in this city until his death in 1846 .

There were a number of Scotch musicians in Belfast when he came here, and they all agreed that Murray had not his equal in Scotland; and although the name of Mackenzie was mentioned, it was as a very promising violinist, he being only twenty then. As Murray left Scotland about seven years before Sir A. C. Mackenzie was born, and died before that event, it would not be strange if Sir Alexander had not heard of him

When in the Edinburgh Theatre Royal, in I849, I was much struck with the elder Mackenzie's fine playing, and also with the fact that only overtures by the best composers were performed, no arrangements of operatic or national airs.- Yours obediently,

Belfast, June $I_{5}$ I 898 .

T. S.

\section{BRIEF SUMMARY OF COUNTRY AND COLONIAL NEWS.}

We do not hold ourselves responsible for any opinions expressed in this summary, as all the notices are either collated from the local papers or supplied to us by correspondents.

Chelmsford.-The Chelmsford Association of Church Choirs held its annual festival service in the Parish Church, on the r $4^{\text {th }}$ ult. The united choirs numbered about 300 voices, and they sang the service impressively, especially the Psalms, Frye's effective Magnificat and Nunc dimittis in B flat (written for the occasion), and Hall's anthem "Praise, my soul." Dr. G. F. Huntley presided at the organ and Mr. F. R. Frye conducted.

DURHAM.-The third symphony concert of the Durham Amateur Orchestral Society was given on May 26 , in the Town Hall, when the varied programme included Haydn's "Oxford" Symphony, Mozart's Pianoforte Concerto in D minor (skilfully played by Miss Prust), Weber's "Oberon" Overture, and Gounod's Suite from "Philémon et Baucis." Mr. Duncanson sang Sterndale Bennett's "'Tis jolly to hunt" ("May Queen"). The orchestra acquitted itself with distinction under the baton of its excellent honorary conductor, Mr. Arthur Wallenstein. After the concert Mr. Wallenstein was presented with a Gladstone bag, a dressing case, and an illuminated address as tokens of esteem and appreciation of his untiring efforts.

EAstbourne.-Mr. George Langley, who is well-known as a lecturer on musical subjects, delivered a lecture on "Wagner: his life, work, and influence on opera," at the Pavilion, Devonshire Park, on the gth ult. He concluded an interesting discourse by demonstrating in a very simple and lucid manner the splendid reforms Wagner effected in the domain of opera. Musical illustrations were artistically played by the lecturer.

ELY.-The Triennial Festival of Parish Choirs of the Diocese of Ely was held in the Cathedral, on the 8th ult., at 3 p.m. A total of 795 members of choirs attended, of whom 585 were surpliced and 2 ro unsurpliced ; the orchestra consisted of ninety-four instruments. Mr. H. P. Allen, organist of the Cathedral, presided at the organ. The conductor was the Rev. L. Borissow, Precentor of Trinity College, Cambridge; and it is due to his careful work that 